\title{
HUBUNGAN FASILITAS, KUALITAS PELAYANAN, HARGA DAN TEMPAT TERHADAP KEPUASAN PENGUNJUNG AGROWISATA DI PT. PERKEBUNAN TAMBI, KABUPATEN WONOSOBO
}

\author{
The Correlation Of Facility, Service Quality, Price And Location To The \\ Agrotourism Visitors' Satisfaction In Tambi Plantation Factory, Wonosobo Regency \\ Idris Santoso ${ }^{*}$, Hendrik Johannes Nadapdap ${ }^{2}$ \\ Program Studi Agribisnis, Fakultas Pertanian dan Bisnis, UKSW \\ “Kontak penulis : $\underline{522015050 @ s t u d e n t . u k s w . e d u}$, hendrik.nadapdap@uksw.edu
}

\begin{abstract}
This research was purposed to identify the relationship among the facility, service quality, price and location toward the agrotourism visitors in Tambi Plantation Factory, Wonosobo Regency. The location was selected purposively (purposive) with a consideration that Tambi Plantation Factory was one of the biggest Private Plantation Factory which owned an agrotourism factor in Central Java Province. The research started from January to February 2019. This research was a quantitative descriptive research which done through survey. The sampling technique used in this research was non probality sampling by accidental sampling. The number of respondents involved in this research were 50 respondents of Tambi Tea Agrotourism visitors. The research result showed that facility $\left(X_{1}\right)$ had positive and medium level of relationship and significantly correlated to the visitor's satisfaction $(Y)$, service quality $\left(X_{2}\right)$ showed positive and strong level of relationship and significantly correlated to the visitor's satisfaction $(Y)$, and price $\left(X_{3}\right)$ had positive and medium level of relationship and not significantly correlated to the visitor's satisfaction. Whereas location $\left(X_{4}\right)$ had low level of relationship and not significantly correlated to the visitor's satisfaction (Y).
\end{abstract}

Keywords: facility, service quality, price, agrotourism visitors' satisfaction.

\section{Abstrak}

Penelitian ini bertujuan untuk mengetahui hubungan fasilitas, kualitas pelayanan, harga dan tempat terhadap kepuasan pengunjung Agrowisata di PT Perkebunan Tambi, Kabupaten Wonosobo. Pemilihan lokasi penelitian dilakukan secara sengaja (purposive) dengan pertimbangan bahwa PT Perkebunan Tambi merupakan salah satu perusahaan Perkebunan Besar Swasta yang memiliki sektor Agrowisata di Provinsi Jawa Tengah. Pelaksanaan penelitian dimulai pada Januari s/d Febuari 2019. Penelitian ini menggunakan jenis penelitian deskriptif kuantitatif dengan metode survei. Teknik pengambilan sampel menggunakan pendekatan non probality sampling dengan cara asidental sampling. Jumlah responden dalam penelitian ini sebanyak 50 responden pengunjung di Agrowisata Teh Tambi. Hasil penelitian menunjukkan bahwa fasilitas $\left(X_{1}\right)$ memiliki tingkat hubungan yang sedang dan positif serta berkorelasi signifikan terhadap kepuasan pengunjung $(\mathrm{Y})$, kualitas pelayanan $\left(\mathrm{X}_{2}\right)$ memiliki tingkat hubungan yang kuat dan positif serta berkorelasi signifikan terhadap kepuasan pengunjung $(\mathrm{Y})$ dan harga $\left(\mathrm{X}_{3}\right)$ memiliki tingkat hubungan yang sedang dan positif serta berkorelasi signifikan terhadap kepuasan pengunjung (Y). Sedangkan tempat $\left(\mathrm{X}_{4}\right)$ memiliki tingkat hubungan yang sangat rendah dan postif serta tidak berkorelasi signifikan terhadap kepuasan pengunjung $(\mathrm{Y})$.

Kata Kunci: fasilitas, kualitas pelayanan, harga, pepuasan pengunjung Agrowisata.

Sitasi: Santoso, I., H. J. Nadapdap, 2019. Hubungan Fasilitas, Kualitas Pelayanan, Harga Dan Tempat Terhadap Kepuasan Pengunjung Agrowisata di pt. Perkebunan Tambi, Kabupaten Wonosobo, JSEP 15(2): 135 - 143 


\section{Pendahuluan}

Salah satu sub-sektor pertanian yang memiliki potensi untuk dikembangkan di Indonesia adalah agrowisata, karena sub-sektor ini selain bernilai ekonomi-produksi juga bernilai ekologis dan edukasi. Sektor pertanian dalam arti on-farm tidak bisa lagi sepenuhnya diandalkan sebagai sumber okupasi pedesaan, penyerap tenaga kerja dan basis pertumbuhan pasca revolusi hijau (Salman, 1995), apalagi dengan adanya dampak perubahan iklim yang memerlukan adaptasi (Kamaluddin et.al, 2012). Agrowisata merupakan salah satu destinasi dan obyek pariwisata yang unik dan menarik, karena mengandung kegiatan pertanian yang jarang di temukan dalam keseharian masyarakat kota. Dengan adanya keragaman dan keunikannya yang bernilai tinggi serta diperkuat oleh kekayaan kultural mempunyai daya tarik kuat bagi pengunjung. Salah satu agrowisata yang ada di Kabupaten Wonosobo adalah Agrowisata Teh Tambi yang beralamat di jalan Tambi No.276, Tegalrejo, Sigedang, Kejajar, Kabupaten Wonosobo. (Angraeni, 2015).

Dalam kegiatan berwisata, pengunjung akan diantar pemandu wisata berkeliling kebun teh untuk menikmati keindahan alam sekitar dan belajar tentang budidaya teh serta proses pengolahannya di pabrik. Selain itu kegiatan agrowisata juga menjadi media untuk mempromosikan produk pertanian berupa teh, serta menjadi media pembelajaran bagi pengunjung mulai dari pembelajaran tentang kegiatan usaha dibidang pertanian khususnya di perkebunan teh sampai dengan pelestarian lingkungan (Koswara, 2005). Di Provinsi Jawa Tengah terdapat kecenderungan peningkatan jumlah pengunjung wisata dalam enam tahun terakhir (Tabel-1).

Tabel 1

Jumlah Wisatawan di Provinsi Jawa Tengah Periode Tahun 2011-2016

\begin{tabular}{lcccc}
\hline No & \multicolumn{3}{c}{ Wisatawan/Visitor } \\
\cline { 2 - 5 } & Tahun & $\begin{array}{c}\text { Mancanegara/ } \\
\text { International }\end{array}$ & Domestik/Domestic & Jumlah/ Total \\
\hline 1 & 2011 & 392895 & 21833351 & 22231246 \\
2 & 2012 & 372463 & 25240021 & 25612484 \\
3 & 2013 & 388143 & 29430609 & 29818752 \\
4 & 2014 & 419584 & 29852095 & 30271679 \\
5 & 2015 & 375166 & 31432080 & 31807246 \\
6 & 2016 & 578924 & 36899776 & 37487700 \\
\hline
\end{tabular}

Sumber : (BPS, 2019).

Tabel-1 menunjukkan bahwa jumlah pengunjung/wisatawan mancanegara dan domestik di Provinsi Jawa Tengah meningkat dari tahun ke tahun. Hal ini disebabkan oleh animo atau keinginan masyarakat untuk datang pada sejumlah tempat wisata yang ikut meramaikan pariwisata. Peningkatan jumlah kunjungan menjadi tolak ukur perkembangan daerah wisata yang juga berdampak positif bagi perekonomian masyarakat daerah wisata, hal tersebut terjadi karena melibatkan berbagai stakeholder di bidang pariwisata mulai dari pengusaha hotel, pengusaha transportasi, jasa wisata, restoran, dan pusat ole-ole (Kurnianti dan Tidar, 2018).

Selain itu, peningkatan jumlah pengunjung di Provinsi Jawa Tengah setiap tahun tentunya disebabkan oleh berbagai faktor, salah satunya ialah faktor kepuasan pengunjung terhadap fasilitas, kualitas pelayanan, harga serta tempat agrowisata yang strategis untuk dikunjungi wisatawan. Salah satu objek wisata perkebunan teh di wilayah Wonosobo adalah Agrowisata Teh Tambi. Agrowisata ini merupakan objek wisata alam yang di kelola oleh PT Perkebunan Tambi. 
PT Perkebunan Tambi merupakan salah satu perusahaan Perkebunan Besar Swasta (PBS) yang bergerak pada bidang agribisnis perkebunan teh. PT Perkebunan Tambi memiliki tiga unit perkebunan, yaitu unit perkebunan Tambi, Bedakah, dan Tanjung Sari. Agrowisata Teh Tambi memiliki luas lahan sebesar 829,14 ha. Agrowisata Tambi berada pada ketinggian 1.200-2.000 m.dpl dengan suhu udara minimal 15 o $\mathrm{C}$ dengan suhu maksimal 24 o $\mathrm{C}$. Agrowisata Teh Tambi di lengkapi berbagai fasilitas, seperti homestay, taman bermain, kebun teh, dan pabrik teh. Di tempat Agrowisata ini pengunjung bisa mendapatkan penjelasan mengenai budidaya teh,proses pengolahan dan pemasaran melalui kegiatan menyusuri kebun dan pabrik teh (Safitri, 2012).

Berdasarkan latar belakang diatas, penelitian ini bertujuan untuk mengetahui hubungan fasilitas, kualitas pelayanan, harga dan tempat terhadap kepuasan pengunjung Agrowisata di PT. Perkebunan Tambi, Kabupaten Wonosobo.

\section{Metode Penelitian}

Penelitian ini dilaksanakan di kawasan Agrowisata PT Perkebunan Tambi yang beralamat di Jalan Tambi No. 276, Tegalrejo, Sigedang, Kejajar, Kabupaten Wonosobo. Pemilihan lokasi penelitian dilakukan secara sengaja (purposive), dengan pertimbangan bahwa PT Perkebunan Tambi merupakan salah satu perusahaan Perkebunan Besar Swasta (PBS) yang mengelola Agrowisata perkebunan teh di Provinsi Jawa Tengah. Pengambilan data dilaksanakan pada bulan Januari 2019 sampai Febuari 2019. Penelitian ini menggunakan analisis deskriptif kuantitatif dengan metode survei.

Pengumpulan data dilakukan dengan observasi dan wawancara menggunakan kuesioner. Teknik pengambilan sampel yang digunakan pada penelitian ini adalah non probability sampling yaitu dengan metode accidental sampling. Accidental sampling merupakan teknik pengambilan sampel berdasarkan orang yang kebetulan bertemu dengan peneliti yang dipandang sebagai orang yang cocok untuk dijadikan sebagai sumber data (Sugiyono, 2011). Jumlah sampel yang diambil dalam penelitian ini sebanyak 50 responden. Pengolahan data menggunakan software computer Microsoft Exel 2010 untuk input data, SPSS versi 17.0 for windows untuk pengujian tiga uji, yaitu: uji validitas, uji reliabilitas, dan uji korelasi rank spearman. Untuk mendapatkan keabsahan data yang diteliti maka dilakukan uji validitas, uji reliabiltas, dan uji korelasi rank spearman dan uji t. Untuk melihat tingkat hubungan digunakan tingkat hubungan menurut (Sugiyono, 2014), yaitu 0,00-0,019 tingkat hubungan sangat rendah, 0,20-0,39 rendah, 0,040-0,59 kuat dan 0,80-0,100 sangat kuat. Untuk melihat tingkat signifikansi digunakan uji t dengan signifikansi 0,05.

Pada penelitian ini telah dilakukan pengujian instrumen penelitian untuk mengetahui kevalidan, keandalan, dan kelayakan data untuk proses analisis selanjutnya. Pengujian instrumen penelitian menggunakan uji validitas dan uji reliabilitas. Hasili uji validitas dapat dilihat pada Tabel-3.

Tabel-3 menunjukkan hasil pengujian validitas dari masing-masing variabel meliputi variabel fasilitas, kualitas pelayanan, harga dan tempat terhadap kepuasan pengunjung Agrowisata. Setelah dilakukan uji validitas, diperoleh nilai koefisien korelasi lebih besar dari r-tabel. Dengan $n=50$ pada tingkat kepercayaan $0,05 \%, r$ - tabel $=2,78$ sehingga dapat dinyatakan bahwa variabel fasilitas, kualitas pelayanan, harga dan tempat terhadap kepuasan pengunjung valid dan bisa dilanjutkan untuk pengujian ketahap selanjutnya. 
Tabel-3

Uji Validitas

\begin{tabular}{lcccc}
\hline Variabel Penelitian & Item & $\begin{array}{c}\text { Koefisien } \\
\text { Korelasi }\end{array}$ & r-tabel $(0,05 \%)$ & Keterangan \\
\hline Fasilitas $\left(\mathrm{X}_{1}\right)$ & $\mathrm{X}_{1.1}$ & 0,618 & 0,278 & Valid \\
& $\mathrm{X}_{1.2}$ & 0,670 & 0,278 & Valid \\
& $\mathrm{X}_{1.3}$ & 0,631 & 0,278 & Valid \\
& $\mathrm{X}_{1.4}$ & 0,783 & 0,278 & Valid \\
\hline Kualitas Pelayanan $\left(\mathrm{X}_{2}\right)$ & $\mathrm{X}_{2.1}$ & 0,588 & 0,278 & Valid \\
& $\mathrm{X}_{2.2}$ & 0,730 & 0,278 & Valid \\
& $\mathrm{X}_{2.3}$ & 0,717 & 0,278 & Valid \\
& $\mathrm{X}_{2.4}$ & 0,734 & 0,278 & Valid \\
\hline Harga $\left(\mathrm{X}_{3}\right)$ & $\mathrm{X}_{3.1}$ & 0,708 & 0,278 & Valid \\
& $\mathrm{X}_{3.2}$ & 0,700 & 0,278 & Valid \\
& $\mathrm{X}_{3.3}$ & 0,760 & 0,278 & Valid \\
& $\mathrm{X}_{3.4}$ & 0,637 & 0,278 & Valid \\
\hline Tempat $\left(\mathrm{X}_{4}\right)$ & $\mathrm{X}_{4.1}$ & 0,701 & 0,278 & Valid \\
& $\mathrm{X}_{4.2}$ & 0,856 & 0,278 & Valid \\
& $\mathrm{X}_{4.3}$ & 0,457 & 0,278 & Valid \\
\hline Kepuasan Pengunjung $(\mathrm{Y})$ & $\mathrm{X}_{4.4}$ & 0,854 & 0,278 & Valid \\
& $\mathrm{Y}_{1.1}$ & 0,792 & 0,278 & Valid \\
& $\mathrm{Y}_{1.2}$ & 0,777 & 0,278 & Valid \\
& $\mathrm{Y}_{1.3}$ & 0,813 & 0,278 & Valid \\
\hline
\end{tabular}

Tabel-4 menunjukkan hasil dari uji reliabilitas meliputi variabel fasilitas, kualitas pelayanan, harga dan tempat terhadap kepuasan pengunjung Agrowisata memperoleh nilai Cronbach's Alpha > 0,6 sehingga dapat dinyatakan bahwa lima indikator sudah reliabel.

Tabel 4

Hasil Uji Reliabilitas Cronbach's Alpha

\begin{tabular}{lcc}
\hline \multicolumn{1}{c}{ Variabel Penelitian } & Cranbach's Alpha & Keterangan \\
\hline Fasilitas $\left(\mathrm{X}_{1}\right)$ & 0,601 & Reliabel \\
Kualitas Pelayanan $\left(\mathrm{X}_{2}\right)$ & 0,638 & Reliabel \\
Harga $\left(\mathrm{X}_{3}\right)$ & 0,625 & Reliabel \\
Tempat $\left(\mathrm{X}_{4}\right)$ & 0,648 & Reliabel \\
Kepuasan Pengunjung $(\mathrm{Y})$ & 0,786 & Reliabel \\
\hline
\end{tabular}

\section{Hasil dan Pembahasan}

\section{A. Profil Pengunjung}

Profil pengunjung wisata PT. Perkebunan Tambi mencakup jenis kelamin, usia, tingkat pendidikan, pekerjaan, penghasilan dan jumlah kunjungan dapat dilihat pada Tabel5. 
Tabel-5

Karakteristik Pengunjung Wisata

\begin{tabular}{|c|c|c|c|}
\hline No & $\begin{array}{c}\text { Profil Responden Berdasarkan } \\
\text { Jenis Kelamin }\end{array}$ & Frekuensi (Orang) & Presentase $(\%)$ \\
\hline 1 & Perempuan & 26 & 52,0 \\
\hline \multirow[t]{3}{*}{2} & Laki-laki & 24 & 48,0 \\
\hline & Total & 50 & 100 \\
\hline & Usia (Tahun) & & \\
\hline 3 & $22-26$ & 14 & 28,0 \\
\hline 4 & $27-31$ & 13 & 26,0 \\
\hline 5 & $32-36$ & 8 & 16,0 \\
\hline 6 & $37-41$ & 10 & 20,0 \\
\hline 7 & $42-46$ & 3 & 6,0 \\
\hline \multirow[t]{3}{*}{8} & $47-51$ & 2 & 4,0 \\
\hline & Total & 50 & 100 \\
\hline & Tingkat Pendidikan & & \\
\hline 9 & SLTA & 12 & 24,0 \\
\hline 10 & D3 & 2 & 4,0 \\
\hline 11 & S1 & 33 & 66,0 \\
\hline \multirow[t]{3}{*}{12} & S2 & 3 & 6,0 \\
\hline & Total & 50 & 100 \\
\hline & Pekerjaan & & \\
\hline 13 & Wiraswasta & 17 & 34,0 \\
\hline \multirow[t]{3}{*}{14} & PNS & 33 & 66,0 \\
\hline & Total & 50 & 100 \\
\hline & Penghasilan (Juta) & & \\
\hline 15 & $0-1,5$ juta & 2 & 4,0 \\
\hline 16 & $1,5-3$ & 10 & 20,0 \\
\hline 17 & $3-4,5$ & 28 & 56,0 \\
\hline 18 & $4,5-6$ & 6 & 12,0 \\
\hline 19 & $6,5-7$ & 2 & 4,0 \\
\hline \multirow[t]{3}{*}{20} & $>7$ & 2 & 4,0 \\
\hline & Total & 50 & 100 \\
\hline & Jumlah Kunjungan & & \\
\hline 21 & 1 kali & 19 & 40,0 \\
\hline 22 & 2 kali & 22 & 44,0 \\
\hline 23 & 3 kali & 7 & 16,0 \\
\hline \multirow{2}{*}{24} & 4 kali & 2 & 4,0 \\
\hline & Total & 50 & 100 \\
\hline
\end{tabular}

Tabel-5 menunjukkan bahwa pengunjung Agrowisata PT. Perkebunan Teh Tambi dominan berjenis kelamin perempuan sebanyak 26 orang $(52 \%)$, usia responden dominan pada rentang usia 22-26 tahun yakni sebanyak 14 orang (28\%), tingkat pendidikan pengunjung dominan lulusan pendidikan Sarjana (S1) yakni sebanyak 33 orang (66\%), pekerjaan pengunjung dominan berprofesi sebagai Pegawai Negeri Sipil (PNS) yakni sebanyak 33 orang $(66 \%)$ dan penghasilan pengunjung dominan sebesar 3 juta $-4,5$ juta yakni sebanyak 28 orang (56\%) serta jumlah kunjungan dominan dua kali yakni sebanyak 22 orang $(44 \%)$. 


\section{B. Hubungan Fasilitas, Kualitas Pelayanan, Harga, dan Tempat terhadap Kepuasan Pengunjung}

Hubungan fasilitas, kualitas pelayanan, harga dan tempat terhadap kepuasan pengunjung di Agrowisata PT Perkebunan Tambi, Kabupaten Wonosobo, dapat diketahui melalui uji Korelasi Rank Spearman $\left(\mathrm{r}_{\mathrm{s}}\right)$. Hasil dari analisis Korelasi Rank Spearman terhadap masing-masing variabel Fasilitas $\left(X_{1}\right)$, Kualitas Pelayanan $\left(X_{2}\right)$, Harga $\left(X_{3}\right)$, dan Tempat $\left(X_{4}\right)$ terhadap Kepuasan Pengunjung Agrowisata $(Y)$ dapat dilihat pada tabel sebagai berikut.

Tabel 5

Hubungan Karakterisitik Fasilitas (X1), Kualitas Pelayanan (X2), Harga (X3) dan Tempat (X4) Terhadap Kepuasan Pengunjung (Y)

\begin{tabular}{|c|c|c|c|c|c|c|c|}
\hline No & Variabel & rs & Sig & $\begin{array}{c}\mathrm{t}- \\
\text { hitung }\end{array}$ & $\begin{array}{c}\mathrm{t}- \\
\text { tabel }\end{array}$ & Keterangan & $\begin{array}{c}\text { Tingkat } \\
\text { Hubungan }\end{array}$ \\
\hline 1 & Fasilitas $\left(\mathrm{X}_{1}\right)$ & $0,439^{(* *)}$ & 0,001 & 3,38 & 1,67 & Signifikan & Sedang \\
\hline 2 & $\begin{array}{l}\text { Kualitas } \\
\text { pelayanan }\left(\mathrm{X}_{2}\right)\end{array}$ & $0,697^{(* *)}$ & 0,000 & 6,73 & 1,67 & Signifikan & Kuat \\
\hline 3 & Harga $\left(X_{3}\right)$ & $\left.0,555^{(* *}\right)$ & 0,000 & 4,61 & 1,67 & Signifikan & Sedang \\
\hline 4 & Tempat $\left(X_{4}\right)$ & 0,154 & 0,284 & 1,07 & 1,67 & $\begin{array}{c}\text { Tidak } \\
\text { Signifikan }\end{array}$ & Sangat Rendah \\
\hline
\end{tabular}

Keterangan: **: Signifikan pada tingkat kesalahan $\alpha=1 \%$

* : Signifikan pada tingkat kesalahan $\alpha=5 \%$

\section{Hubungan Fasilitas (X1) Terhadap Kepuasan Pengunjung (Y)}

Berdasarkan hasil uji analisis korelasi rank spearman pada Tabel-5, diketahui bahwa nilai koefisien korelasi antara variabel fasilitas $\left(\mathrm{X}_{1}\right)$ terhadap kepuasan pengunjung $(\mathrm{Y})$ sebesar 0,439 dengan tanda positif dan signifikan pada taraf kepercayaan $95 \%$. Hal tersebut menunjukkan bahwa variabel fasilitas memiliki hubungan yang positif serta tingkat hubungannya sedang terhadap kepuasan pengunjung, dimana nilai koefisien variabel fasilitas berada pada interval 0,40-0,59. Hal ini sesuai dengan interpretasi kuatnya hubungan korelasi menurut (Sugiyono, 2014). Hal itu juga dapat dilihat pada hasil uji t yaitu nilai $t-$ hitung 3,38 > 1,67 t-tabel yang menunjukkan bahwa variabel fasilitas berkorelasi signifikan terhadap kepuasan pengunjung. Artinya fasilitas menjadi salah satu faktor yang membuat pengunjung merasa puas, karena dengan adanya fasilitas yang lengkap di tempat agrowisata pengunjung akan merasa nyaman selama berkunjung karena fasilitas yang lengkap tersebut. Dari hasil temuan di lapangan peneliti melakukan wawancara dengan beberapa pengunjung Agrowisata Teh Tambi, dari hasil wawancara tersebut pengunjung menganggap bahwa fasilitas yang disediakan pihak agrowisata sudah cukup lengkap untuk memenuhi kebutuhan pengunjung. Adapun fasilitas yang disediakan oleh pihak pengelola Agrowisata Teh Tambi mencakup mushola, toko souvenir, homestay, wifi dan lain sebagainya dalam memenuhi kebutuhan pengunjung.

Hal ini sesuai dengan hasil penelitian yang dilakukan Oktaviana (2012), yang menyatakan bahwa terdapat hubungan positif dan signifikan antara fasilitas dengan kepuasan konsumen. Menurut Tjiptono (2012), fasilitas dalam perusahaan jasa merupakan faktor krusial yang berpengaruh terhadap kesuksesan suatu perusahaan jasa, fasilitas yang baik dapat memberikan beberapa manfaat bagi perusahaan seperti loyalitas yang timbul setelah konsumen merasa puas dari layanan fasilitas yang diberikan dan nilai positif untuk perusahaan. 


\section{Hubungan Kualitas Pelayanan (X2) Terhadap Kepuasan Pengunjung (Y)}

Berdasarkan hasil uji analisis korelasi rank spearman pada Tabel-5, diketahui nilai koefisien korelasi antara variabel kualitas pelayanan $\left(X_{2}\right)$ terhadap variabel kepuasan pengunjung $(\mathrm{Y})$ sebesar 0,697 dengan tanda positif dan signifikan pada taraf kepercayaan $95 \%$. Hal tersebut menunjukkan bahwa faktor kualitas pelayanan memiliki hubungan yang positif serta tingkat hubungannya kuat terhadap kepuasan pengunjung. Hal ini mengacu pada tabel tingkat hubungan dimana nilai koefisien variabel kualitas pelayanan berada pada interval 0,60-0,79 sesuai dengan interpretasi kuatnya hubungan korelasi menurut Sugiyono (2014). Hal itu juga dapat dilihat pada hasil uji t yaitu nilai t-hitung 6,73 > 1,67 t-tabel menunjukkan bahwa variabel kualitas pelayanan berkorelasi signifikan terhadap variabel kepuasan pengunjung. Artinya jika pihak perusahaan/pihak pengelola agrowisata memberikan pelayanan yang terbaik dalam melayani setiap pengunjung yang datang maka pengunjung akan merasa puas dan senang dengan apa yang mereka dapatkan ditempat agrowisata tersebut. Dari hasil wawancara dengan beberapa pengungjung Agrowisata Teh Tambi mereka merasa puas/senang dengan pelayanan yang diberikan oleh pihak pengelola karena dari pertama kali datang ke tempat agrowisata pengunjung langsung disambut oleh karyawan yang bertugas dengan ramah serta disuguhkan minuman teh, karyawannya juga cepat dan tanggap dalam melayani kebutuhan pengunjung serta selalu bersikap sopan kepada pengunjung yang baru datang maupun yang sudah datang di sana sehingga menyebabkan pengunjung merasa puas dengan kualitas pelayanan yang diberikan.

Hal ini sesuai dengan penelitian Putri dan Fatmasari (2018) yang menyatakan bahwa terdapat hubungan positif dan signifikan antara kualitas pelayanan terhadap kepuasan pelanggan. Menurut Lupiyoadi (2009), kualitas pelayanan yang baik yang diberikan oleh karyawan terhadap konsumen akan berpengaruh secara nyata terhadap kepuasan konsumen, dimana kualitas pelayanan yang buruk akan berakibat fatal terhadap ketidakpuasan konsumen sehingga konsumen menjadi tidak loyal.

\section{Hubungan Harga (X3) Terhadap Kepuasan Pengunjung (Y)}

Berdasarkan hasil uji analisis korelasi rank spearman pada Tabel-5 diketahui nilai koefisien korelasi antara variabel harga (X3) terhadap variabel kepuasan pengunjung (Y) sebesar 0,555 dengan tanda positif dan signifikan pada taraf kepercayaan 95\%. Hal tersebut menunjukkan bahwa faktor harga memiliki hubungan yang positif serta tingkat hubungan yang sedang terhadap kepuasan pengunjung. Hal ini mengacu pada tabel tingkat hubungan, dimana nilai koefisien variabel harga berada pada interval 0,40-0,59 sesuai dengan interpretasi kuatnya hubungan korelasi menurut Sugiyono (2014). Hal itu juga dapat dilihat pada hasil uji $\mathrm{t}$ yaitu nilai $\mathrm{t}$-hitung 4,61 > 1,67 t-tabel menunjukkan bahwa variabel harga berkorelasi signifikan terhadap variabel kepuasan pengunjung. Artinya harga menjadi salah satu faktor yang menentukan kepuasan pengunjung, karena apabila harga yang ditawarkan pihak agrowisata sesuai dengan fasilitas yang didapatkan pengunjung maka pengunjung akan cenderung merasa puas berapapun harga yang di tawarkan. Biasanya pengunjung akan tetap puas jika harga tersebut sesuai dengan apa yang mereka dapatkan pada saat berkunjung. Dari hasil wawancara di lapangan dengan pengunjung Agrowisata Teh Tambi mengenai harga yang ditawarkan oleh pihak pengelola, mereka beranggapan bahwa harga yang ditawarkan sudah sesuai dengan fasilitas yang di dapatkan oleh pengunjung pada saat melakukan kunjungan dan rata-rata responden yang melakukan kunjungan ke Agrowisata Teh Tambi secara rombongan dan ada juga yang dibiayai instasi terkait sehingga biaya yang dikeluarkan pengunjung tidak terlalu besar.

Hal ini sesuai dengan penelitian yang dilakukan oleh Edison dan Tonoto (2018), yang menyatakan bahwa terdapat hubungan positif dan signifikan antara harga terhadap 
kepuasan pelanggan. Menurut Kotler (2009), harga merupakan sejumlah uang yang dibebankan atas suatu produk/jasa atau jumlah nilai yang ditukar konsumen untuk manfaat-manfaat yang diterima karena menggunakan produk/jasa tersebut.

\section{Hubungan Tempat (X4) Terhadap Kepuasan Pengunjung (Y)}

Berdasarkan hasil uji analisis korelasi rank spearman pada Tabel-5, nilai koefisien korelasi antara variabel tempat (X4) terhadap kepuasan pengunjung (Y) sebesar 0,154 dengan tanda positif tetapi signifikan pada tingkat kepercayaan (95\%). Hal tersebut menunjukkan bahwa faktor tempat memiliki hubungan yang positif serta tingkat hubungannya sangat rendah terhadap kepuasan pengunjung, hal ini mengacu pada tabel tingkat hubungan dimana nilai koefisien variabel tempat berada pada interval 0,00-0,19 sesuai dengan interpretasi kuatnya hubungan korelasi menurut (Sugiyono, 2014). Hal itu juga dapat dilihat pada hasil uji t yaitu nilai t-hitung 1,07 <1,67 t-tabel menunjukkan bahwa variabel tempat berkorelasi tidak signifikan terhadap kepuasan pengunjung. Artinya walaupun tempat agrowisata tersebut mudah dijangkau dan diakses sarana transportasi umum, dekat dengan pemukiman warga, dan terlihat dari pinggir jalan, tetapi tidak ada hubunganya dengan kepuasan pengunjung karena pengunjung akan mencari alternatif tempat lain untuk mereka kunjungi dan mendapatkan kepuasan yang lebih. Dari hasil wawancara dengan pengunjung di Agrowisata Teh Tambi pengunjung masih banyak belum mengetahui informasi mengenai Agrowisata Teh Tambi tersebut dan rata-rata dari mereka menjawab hanya mengetahui lokasi Agrowisata tersebut dari mulut ke mulut saja sehingga pada saat mereka melakukan kunjungan ada yang tidak sesuai dengan ekspektasi dan menyebabkan pengunjung tidak puas pada saat berwisata sehingga mereka berpindahpindah dalam melakukan kunjungan untuk mencari kepuasan, karena di daerah Dieng banyak alternatif tempat wisata untuk dikunjungi.

\section{Kesimpulan}

Berdasarkan hasil analisis dalam penelitian ini maka diperoleh kesimpulan bahwa fasilitas $\left(X_{1}\right)$ memiliki tingkat hubungan yang sedang dan positif serta berkorelasi signifikan terhadap kepuasan pengunjung $(\mathrm{Y})$, kualitas pelayanan $\left(\mathrm{X}_{2}\right)$ memiliki tingkat hubungan yang kuat dan positif serta berkorelasi signifikan terhadap kepuasan pengunjung $(Y)$ dan harga $\left(X_{3}\right)$ memiliki tingkat hubungan yang sedang dan positif serta berkorelasi signifikan terhadap kepuasan pengunjung $(Y)$. Sedangkan tempat $\left(X_{4}\right)$ memiliki tingkat hubungan yang sangat rendah dan postif serta tidak berkorelasi signifikan terhadap kepuasan pengunjung (Y).

\section{Daftar Pustaka}

BPS. 2019. Jumlah Wisatawan Mancanegara dan Domestik di Provinsi Jawa Tengah Periode Tahun 2011- 2016. https://jateng.bps.go.id. Diakses pada tanggal 27 Januari 2019: Salatiga.

Edison, G. dan Tonoto, S.R., 2018. Hubungan Harga dan Kualitas Layanan Terhadap Kepuasan Pelanggan M- Sport Futsal Center.

Kamaluddin, A., A. Ala, MSS. Ali, D. Salman, 2012. "The Adaptation of Rice Paddy Farmers Towards Climate Change". American-Eurasian Journal of Agricultural and Environmental Science. 12 (7). 
Kotler, P., 2009. Manajemen Pemasaran.Cetakan ketiga belas. Jilid 1. Jakarta: Erlangga.

Lupiyoadi, R. dan Hamdani, 2009. Manajemen Pemasaran Jasa. Edisi Ke 2. Jakarta: Salemba Empat.

Oktaviana, M., 2012. Hubungan Lokasi, Harga, Fasilitas dan Pelayanan dengan Kepuasan Konsumen Di Blackball Waroeng Billiard Demangan. Thesis. Yogyakarta: Fakultas Ilmu Keolahragaan Universitas Negeri Yogyakarta.

Putri, V. A., dan Fatmasari, D., 2018. Hubungan Kualitas Pelayanan Dengan Kepuasan Pelanggan Alfamart di Kelurahan Srondol Wetan Semarang. Majalah Ilmiah Inspiratif, 3(5).

Safitri, A.D., 2012. Analisis Strategi Pengembangan Usaha Wisata Agro Tambi Kecamatan Kejajar, Kabupaten Wonosobo.

Salman, D., 1995. “Arah Perubahan Sosial di Pedesaan Pasca Revolusi Hijau”. Analisis, XXIV, No.1.

Sugiyono, 2014. Metode Penelitian Kuantitatif, Kualitatif dan RED Cetakan ke 13. Bandung: Alfabeta.

Tjiptono, 2012. Service Management Mewujudkan Pelayanan Prima. Yogyakarta: Andi. 